governments of Europe will establish some kind of talking shop within which research councils, public research foundations and universities can begin to work out what needs to be accomplished. Quite independently of whether the European Community is to be enlarged, this is a task that could be attempted right away.

Further away is the problem of how money should be spent on European research. For the time being, at least, it is to be expected that the member nations of the European Community will regard what they spend on higher education and basic research as a long-term investment in national well-being or even prosperity. Their justification for this expenditure will often rest on the belief that such expenditure will improve their competitive position within the communities With luck, in other words, natural rivalry should help to ensure that European governments spend generously on higher education and basic research in the decade or so ahead. But this is bound to be a passing phase. As soon as there emerges a rational pattern of research, it will also be necessary to work out ways of coordinating expenditures of funds. That will be the point at which governments with large budgets for research and higher education will be looking askance at those who drag their feet. At the same time, it will be necessary for governments (and taxpayers) to accept that national resources should be spent on foreign enterprises. At this stage, it is hard to see how governments can be prevented from tearing each other to pieces without an international budget for research and higher education. The fact that such a goal is bound, at present, to seem distant should not allow those who administer public expenditure on research and development to shy away from the fact that the planning must be done now, and not shelved until some future date.

\title{
From Prayer-meeting to Trade Fair
}

THE fourth United Nations Conference on the Peaceful Uses of Atomic Energy, now finishing at Geneva, is a remarkable proof of how rapidly it has been possible to convert a bright idea into a workable and sophisticated technology. It is also a powerful demonstration of the way in which technological innovations should be introduced to those most likely to benefit from them with a greater sense of sobriety than that attending the first United Nations conference in 1955 . Will the sponsors learn the lesson now staring everybody in the face?

Fifteen years ago, nuclear power was still largely military in character. The first United Nations conference was remarkable for the way in which it helped the governments of the nuclear powers to put some of their secret cards on an open table. Even such facts of nature as the cross-sections of nuclear reactions involving neutrons were secret, and it seemed at the time to be a great discovery for all concerned that measurements on both sides of what was then called the Iron Curtain tended to be roughly in agreement with each other. To be sure, it was at the time a puzzle to know just why the nuclear powers had decided to make a partially clean breast of the information which they had acquired in the pursuit of military objectives. Perhaps they were responding honestly to the complaint of non-nuclear nations that it would be intolerable if the Great Powers were able to hang on to what seemed to be a monopoly in the exploitation of an important and beneficial technology. It may be that the initiative of President Eisenhower, who launched from the United States an international programme with the slogan "Atoms for Peace", struck a genuine response from the Soviet Union and the United Kingdom. It may even be, as the sceptics were inclined at the time to protest, that all concerned had their eyes on the main chance-the opportunity for making important sales of equipment. In any case, there is in retrospect no doubt that the promise of nuclear energy was spelt out with too much enthusiasm, and that in the process the development of the industry was hindered and not helped. The moral is that in the launching of a new technology, as in the launching of a business enterprise, it is imprudent to publish too cheerful a prospectus.
A second lesson to be learned from the past two weeks at Geneva is that technical progress in nuclear power has been as rapid as anybody could realistically expect. Fifteen years ago, even thermal reactors were entirely novel. Only the foolhardy talked seriously of fast reactors. Although there has since been all kinds of false excitement about fusion reactors, it does now seem as if thermonuclear power is about to be a reality. The importance of this development cannot be exaggerated-it is tantamount to freedom from anxiety about energy supplies in the foreseeable future. That makes up for all kinds of errors.

\section{Years Ago}

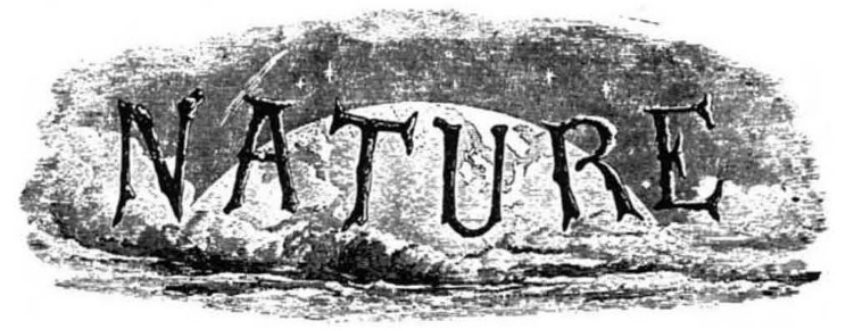

THE preparations made by the Governments of the present age to have every phase of a total eclipse studied and recorded, contrast favourably with the superstition that prevailed a few centuries ago. For instance, the Scient,fic Anerican quotes the following from a German paper :- "The Elector of Darmstadt was informed of the approach of a total eclipse in 1699, and published the following edict in consequence :- 'His Highuess, having been informed that on Wednesday morning next at ten o'clock a very dangerous eclipse will take place, orders that on the day previous, and a few days afterwards, all cattle be liept housed, and to this end ample fodder be provided; the doors and windows of the stalls to be carefully secured, the drinking welis to be covered up, the cellars and garrets guarded so that the bad atmosphere may not obtain lodgment, and thus produce infection, because such eclipses frequently occasion whooping cough, epilepsy, paralysis, fever, and other diseases, against which every precaution should be observed.'"

From Nature, 4, 418, September 21, 1871 